\title{
13-NOV-1996 BLDSC
}

WEED SCIENCE

\section{PHYSIOLOGY, CHEMISTRY, AND BIOCHEMISTRY}

Effect of Low Doses of Metamitron and Glyphosate on Growth and Chlorophyll Content of Common Lambsquarters (Chenopodium album). David H. Ketel

Synthesis and Herbicidal Activity of Modified Monoterpenes Structurally Similar to Cinmethylin. Steven F. Vaughn and Gayland F. Spencer

Physiological Basis for Differential Sensitivity to Sylfentrazone by Sicklepod (Senna obtusifolia) and Coffee Senna (Cassia occidentalis). Franck E. Dayan, John D. Weete, and H. Gary Hancock

Absence of Differential Fitness Between Giant Foxtail (Setaria faberi) Accessions Resistant and Susceptible to Acetyl-Coenzyme A Carboxylase Inhibitors. Ronald J. Wiederholt and David E. Stoltenberg

Resistance to Aryloxyphenoxypropionate and Cyclohexanedione Herbicides in Green Foxtail (Setaria virdis). Ian M. Heap and lan M. Morrison

Influence of Imazethapyr on Rhizobium Growth and its Symbiosis with Pea (Pisum sativum). A. Gonzalez, C. Gonzalez-Murua, and M. Royuela

Adjuvant-Increased Glyphosate Uptake by Protoplasts Isolated from Quackgrass Elytrigia repens (L.) Nevski. Hans de Ruiter and Esther Meinen

\section{WEED BIOLOGY AND ECOLOGY}

A Comparison of Methods to Predict Weed Seedling Populations From the S

Applications of an Ecophysiological Model for Irrigated Rice (Oryza sativa)- $t$ a Competition. John L. Lindquist and Martin J. Kropff

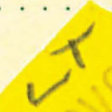

Effects of Vernalization on Flowering in Ripgut Brome (Bromus diandrus). Jean A. Gleichsner and Arnold P. Appleby

Temperature Effects on Vegetative Growth of Round-Leaved Mallow (Malva pusilla). Robert E. Blackshaw

Reproductive Behaviour of Natural Populations of Meadow Salsify (Tragopogon pratensis). Meiqin Qi, Mahesh K. Upadhyaya, and Roy Turkington

Seed Longevity of 41 Weed Species Buried 17 Years in Eastern and Western Nebraska. Orvin G. Burnside, Robert G. Wilson, Sanford Weisberg, and Kenneth G. Hubbard

Physiological Basis of Seed Dormancy in Woolly Cupgrass (Eriochloa villosa [Thumb.] Kunth.). Harlene Hatterman-Valenti, Iliya A. Bello, and Micheal D. K. Owen

Effects of Temperature and Water Potential on Germination of Horehound (Marrubium vulgare) Seeds from two Australian Localities. Attila Lippai, Paula A. Smith, Terence V. Price, John Weiss, and Christopher J. Lloyd

Dynamics of Seed Bank and Survivorship of Meadow Salsify (Tragopogon pratensis) Populations. Meiqin Qi, Mahesh K.

Upadhyaya, and Roy Turkington

Phytochrome Action in Seed Germination of Fringed Sage (Artemisia frigida). Yuguang Bai, James T. Romo, and Junqiang Hou

Canada Thistle (Cirsium arvense) Effects on Yield Components of Spring Wheat (Triticum aestivum). William W. Donald and Mohammad Khan

Diurnally Alternating Temperatures Stimulate Sprouting of Purple Nutsedge (Cyperus rotundus) Tubers. Joel E. Miles, Roy K.

\section{LOAN BAN EXPRES 14 MAY 1997}




\section{WEED MANAGEMENT}

Decision Rules for Postemergence Control of Pigweed (Amaranthus spp.) in Soybean (Glycine max). Anita Dieleman, Allan S.

Hamill, Glenn C. Fox, and Clarence J. Swanton

Effect of Crop Species, Tillage, and Rye (Secale cereale) Mulch on Sicklepod (Senna obtusifolia). Barry J. Brecke and Donn G.

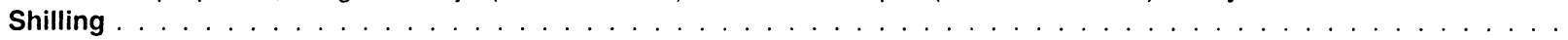

MSMA and Pyrithiobac Effects on Cotton (Gossypium hirsutum) Development, Yield and Quality. Mark W. Shankle, Robert M.

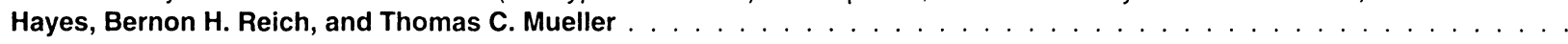

Influence of Nontarget Neighbors and Spray Volume on Retention and Efficacy of Triclopyr in Purple Loosestrife (Lythrum salicaria).

Elizabeth J. Stamm Katovich, Roger L. Becker, and Brad D. Kinkaid . . . . . . . . . . . . . . . . . . . . . . .

Weed Control With Reduced Rates of Four Soil Applied Soybean Herbicides. Kilwake C. Muyonga, Michael S. DeFelice, and

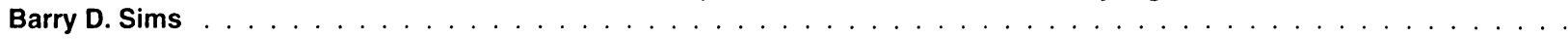

\section{SOIL, AIR, AND WATER}

Cotton (Gossypium hirsutum) Response to Imazaquin and Imazethapyr Soil Residues. David H. Johnson and Ronald E. Talbert .

Effects of Tillage on Chlorimuron Persistence. Todd A. Baughman, David R. Shaw, G. Neil Rhodes, Jr., and Thomas C. Mueller .

Sorption and Mobility of Bentazon in Coastal Plain Soils. Timothy L. Grey, Glenn R. Wehtje, Den F. Hajek, and Robert H. Walker .

Effect of Long-term Vetch (Vicia villosa) Cover Crop and Tillage System on Fluometuron Disspation from Soil Surface. Blake A.

Brown, Robert M. Hayes, Donald D. Tyler, and Thomas C. Mueller

\section{SPECIAL TOPICS}

The Evolution and Genetics of Herbicide Resistance in Weeds. Marie Jasieniuk, Anita L. Brûlé-Babel, and lan M. Morrison . . .

Using Spatial Information Technologies to Map Chinese Tamarisk (Tamarix chinensis) Infestations. James H. Everitt, David E.

Escobar, Mario A. Alaniz, Michael R. Davis, and James V. Richerson . . . . . . . . . . . . . . . . . . . . . . . . . 


\title{
WEED SCIENCE
}

\section{Published four times a year by the Weed Science Society of America}

Robert L. Zimdahl, Editor

\section{Associate Editors}

D. D. Buhler, USDA-ARS, National Soil Tilth Lab, 2150 Pammel Dr., Ames, IA 50(011

Nicholas Jordan, Dept. Agron/Plant Genetics, Univ. of Minnesota, 1991 Buford Circle. St. Paul. MN 55108

R. J. Kremer, USDA-ARS, 144 Mumford Hall, University of Missouri, Columbia, MO 65211

Tom Mueller, Plant/Soil Science Department. University of Tennessee, P.O. Box 1071, Knoxville. TN 37901

Karen Ann Renner, Crop and Soil Sciences, Michigan State University. 466 Plant/Soil Science Bldg.. E. Lansing. MI 48824

Dale Shaner, American Cyanamid Co., P.O. Box 40(), Princeton, NJ (08540)

C. E. Snipes, Delta Branch Exp. Sta., P.O. Box 197, Stoneville, MS 38776

Susan E. Weaver, Agriculture Canada, Research Station, Harrow, ON. Canada NOR IG0)

Allen F. Wiese, Texas Agricultural Experiment Station, Texas A\&M University System, P.O. Box Drawer 10, Bushland. TX 79012

Lori J. Wiles, Great Plains Systems Res., USDA ARS, 301 S. Howes, Rm. 353, Ft. Collins, CO 80522

\section{Gayle Rodcay, Technical Editor}

\section{Reviewers}

$\begin{array}{lllll}\text { R. E. Blackshaw } & \text { Stephen Hart } & \text { Carol Mallory-Smith } & \text { David Shaw } & \text { Thomas Tworkoski } \\ \text { Jim Burton } & \text { Robert Hartzler } & \text { Diane R. Manthey } & \text { Redi Smeda } & \text { M. K. Upadhyaya } \\ \text { A. G. Dexter } & \text { W. Carroll Johnson } & \text { Bruce Maxwell } & \text { Tracy Sterling } & \text { Glenn Wehtje } \\ \text { William E. Dyer } & \text { Wayne Keeling } & \text { Wondi Mersie } & \text { C. J. Swanton } & \text { Leslie A. Weston } \\ \text { Michael E. Foley } & \text { Martin A. Locke } & \text { Krishna Reddy } & \text { Ronald F. Turco } & \text { John Wilcut }\end{array}$

\section{Officers of the Weed Science Society of America}

\author{
James L. Barrentine, President \\ Charlotte Eberlein. Secretary \\ Stephen O. Duke, President-Ele't \\ Laura L. Whatley. Treasurer \\ Calvin G. Messersmith, Vice President \\ Ann Legere, Editor-in-Chicf \\ Alex G. Ogg, Past President \\ Robert A. Schmidt, Executive Secretary
}

Horace D. Skipper, Chair, Constitution and Operating Procedures

Weed Science (ISSN (0)4.3-1745) is an official publication of the Weed Science Society of America. 1508 West University Ave.. Champaign. Il. 61\$21-31.3.3 (AC/217-352-4212). It contains refereed papers describing the results of research that elucidates the nature of phenomena relating to all aspects of weeds and their control. It is published quarterly, one volume per year, four issues per year beginning in January.

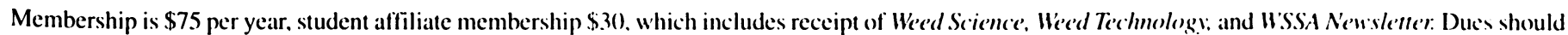
be sent to WSSA, 1508 West University Ave. Champaign, IL 61821-31.33 not later than December 1 of each year. Membership in the societ! is on at calendar-year basis only.

Subscriptions (institutions, libraries, etc.) are $\$ 125$ per year. one volume per year of four issues beginning in January. New subscriptions and renewals begin with the first issue of the current volume and should be sent 10 WSSA. 1508 West University Ave.. Champaign, IL 61821-3133.

Change of address affecting the mailing list for members, students, and subscribers, inquiries about copies lost in the mail. requests for back issues, and all matters pertaining to the receipt of the Journal, membership and subscription information should be sent to WSSA. 1508 West University Ate.. Champaign. IL 61821-3133. Claims for copies lost in the mail must be received within 30) days (90) days foreign) of the date of issue to insure replacement at no charge.

Manuscripts must be sent to the Editor. Robert L. Zimdahl. Weed Research Laboratory, Colorado State University. Fort Collins. CO 80523. Directions for contributors are published in the October-December issue of Weed Science. Authors are asked to pay $\$ 50$ (member) or $\$ 1(0)$ (nonmember) per page charge as a portion of the cost of publication. The Editor can make exceptions in advance when justified.

The Weed Science Society of America fully subscribes to the belief that progress in science depends upon the sharing of ideas, information. and materials among qualified investigators. Authors of papers published in Weed Science are therefore encouraged. whenever practicable and when state and federal laws permit, to share genotypically unique, propagative materials they might possess with other workers in the area who request such materials for the purpose of scientific research.

Weed Science published by the Weed Science Society of America. Second class postage paid at Champaign. IL and at additional mailing offices.

Copyright 1996 by the Weed Science Society of America. Printed in USA.

All rights reserved. Reproduction in part or whole prohibited.

POSTMASTLR: Send address changes to WSSA. 1.508 West University Ave., Champaign. IL 61821-313.3. 


\section{Sustaining Members \\ WEED SCIENCE SOCIETY OF AMERICA \\ December 29, 1995}

\section{Patron}

\section{BASF Corporation}

Cenex/Land O'Lakes

Compliance Service Int'l., Inc.

DowElanco

DuPont Agricultural Products

ISK Bioscience Corporation

Monsanto Agricultural Company

Sandoz Crop Protection

Valent USA Corporation

\section{Contributing}

AgrEvo USA Company

Bayer Corporation

FMC Corporation Ag Chem Group

Griffin Corporation

PBI/Gordon Corporation

Terra Chemical Int'l. Inc.

The Scotts Company

Uniroyal Chemical Company

\section{Associate}

ABC Laboratories

Agri-Growth Research Inc.

Agvise Laboratories

A \& L Agric. Laboratories Inc.

ALMACO Company

American Agricultural Services

American Cyanamid Company
Astrix

Ciba-Geigy Canada Ltd.

Ciba-Geigy Corporation

Concord Environmental Equipment

Decagon Devices, Inc.

Deere \& Company Tech. Center

Ecologistics Limited

EPL Bio-Analytical Services

Gandy Corporation

Growmark Inc.

Gylling Data Management Inc.

HarvestMaster Inc.

Heartland Technologies Inc.

ICMS

Kincaid Equipment Manufacture Corp.

Landis International Inc.

LI-COR Inc.

MARATHON Ag/Environmental

Minnesota Valley Testing Lab.

Mycogen Corporation

Nissan Chemical America Group

R \& D Sprayers, Inc.

Research Options Inc.

Rhone-Poulenc Ag Company

Rohm \& Haas Company

Spraying Systmes Company

Springborn Laboratories Inc.

Stewart Agric. Research Services

The Andersons

Thomson Publications

United Agri Products

Weed Systems Equipment Inc.

Wintersteiger America Inc.

ZENECA Inc. 